\title{
Transplantation Tolerance, Microchimerism, and the Two-Way Paradigm
}

Thomas E. Starzl, Anthony J. Demetris, Noriko Murase, Massimo Trucco, Angus W. Thomson, Abdul S. Rao, and John J. Fung

University of Pittsburgh Medical Center, Pittsburgh, Pennsylvania

\section{INTRODUCTION}

In discussing the two-signal concept of self/nonself discrimination, Melvin Cohn extolled the virtues of immunological hypotheses that accommodate all relevant observations and therefore enunciate principles, as opposed to concise "small theories" that explain only a few facts [1]. Cohn's points are exemplified by transplantation, which developed throughout much of its modern history in the absence of a unifying general principle. The inability to evolve an encompassing explanation for observations made in human and animal allograft recipients, or in surrogate in vitro models, drove much of transplantation research down the same reductionist pathway as that of its handmaiden, immunology.

The resulting triumph of detail over concept can be traced to two premises that were introduced into the still fragile base of transplantation immunology between 1944 and 1959. The first was that the events following transplantation could be defined in terms of one-way immune reactions: host versus graft (HVG) and graft versus host (GVH). This was a potentially defensible framework from which important experiments could be formulated. However, when the first premise was combined with a second assumption, namely, that whole organ allograft "acceptance" must be by different mechanisms than the chimerism-dependent acquired tolerance, by Billingham, Brent, and Medawar $[2,3]$, the result was derivative dogma that we have called "the one-way paradigm" [4].

\section{THE Y IN THE ROAD: 1962}

Ironically, the first examples of successful human renal transplantation were directly responsible for establishment of the intellectually disorienting one-way paradigm. Until 1959, the production of chimerism by donor leukocyte infusion in preparation for organ allotransplantation had been a much anticipated natural extension $[5,6]$ of the neonatal tolerance models $[2,3]$ and the adult rodent ana- 
logues in which recipient conditioning by cytoablation was required for donor cell engraftment $[7,8]$. The threat of graft-versus-host disease (GVHD) $[9,10]$ restricted this strategy to closely histocompatible donor/recipient pairs [5,6,8-11]. However, when long survival of functioning human kidney allografts was accomplished in sublethally irradiated recipients (1959-62) without donor leukocyte infusion [12-14] and then regularly (from 1962 onward) with the additional omission of cytoreduction under continuous pharmacological immunosuppression [15-18], both chimerism and the need for recipient cytoablation seemingly had been eliminated as conditions for organ allograft acceptance.

Once this thought was embedded into the catechism of organ transplantation, it was not challenged for the next 30 years. The first casualty of the consensus was a hypothesis by Simonsen [19] and Michie, Woodruff, and Zeiss [20], who postulated (in 1960-61) that the two populations of immune cells in neonatally tolerant mice managed to coexist in a stable state by becoming mutually nonreactive while retaining the ability to function collaboratively (i.e., in a joint immune response to infection). This heretical suggestion presaged the active network hypotheses of tolerance of Jerne [21], Coutinho [22], and Cohen [23].

The Simonsen hypothesis was recanted in 1962 [24], ostensibly because no experimental support could be found for it. More importantly, however, the hypothesis had been advanced in a nonreceptive climate wherein nothing less than clonal deletion was being seriously considered as the explanation for acquired transplantation tolerance. The disputes during the immediately preceding years about clonal selection as the basis for self/nonself delineation seemingly had achieved closure with the ultimate imprimatur of the Nobel Prize, which was awarded to MacFarland Burnet in $1960[25,26]$.

It was no coincidence that the 1960 colaureate with Burnet was Peter Brian Medawar, whose observations in the neonatal tolerance model (with Rupert Billingham and Leslie Brent $[2,3,11]$ ) were widely considered to be a validation of Burnet's prediction that developing lymphocytes with an open repertoire of receptors could be purged of self-reactive cells before they achieved functional maturity. Similar tolerance produced in radiation chimeras $[7,8]$ also was viewed as an iatrogenically engineered simulation of ontogeny. However, the argument for clonal deletion as the key mechanism of either variety of acquired tolerance was not beyond criticism, as has been pointed out by Schaffner $[25,26]$, Cohn [1], Nossal [27], and Tauber [28].

All factors considered, it was difficult to envision transplantation as a biologically sound undertaking and, in fact. Burnet did not. In 1961, we wrote in the New England Journal of Medicine that "much thought has been given to ways by which tissues or organs not genetically and antigenically identical with the patient might be made to survive and function in the alien environment. On the whole the present outlook is highly unfavorable to success." [29].

\section{THE ONE-WAY PARADIGM}

\section{A. Organ Transplantation}

Part of the appeal of the simplistic one-way paradigm that emerged from the 195963 period was the compatibility of this conceptual framework with Medawar's definition of rejection as a unidirectional host versus defenseless graft (HVG) immune 
response [30] (Figure 1A). When the one-way in vitro tests of immune reactivity were developed [31,32], they were automatically accepted as "minitransplant models," the results from which were assumed to be directly applicable to in vivo circumstances.

\section{B. Bone Marrow Transplantation}

From the perspective of the early 1960s, it also seemed logical to interpret the tolerance induced in rodents with splenocyte $[2,3]$ or subsequently bone marrow transplantation $[3,7,8,11]$ as transposed examples of the one-way paradigm (Figure $1 B$ ) in which the GVH reaction mounted by the immunologically competent allograft rejected the defenseless recipient unless there was a high degree of histocompatibility. This frame of reference guided the major histocompatibility complex(MHC)-limited strategies of recipient cytoablation and "replacement" $[7,8]$ that eventually led to successful clinical bone marrow transplantation in humans - first by Mathe et al. [33] and with mounting frequency after 1968 [34-37]. The clinical achievements encouraged the belief that cytoablation (or cytoreduction) to "make microenvironmental space" was a necessary condition for donor leukocyte engraftment (reviewed in Ref. 38), in spite of early $[39,40]$ and recent evidence $[41]$ to the contrary.

Thus, as had occurred earlier with the engraftment of human kidneys, the success of clinical bone marrow transplantation strengthened the grip of the oneway paradigm, notwithstanding its inability to explain why organ transplantation was governed by different rules than those for bone marrow transplantation (Table 1). At the root of the dilemma lay the assumption that chimerism, the sine qua non of bone marrow transplantation, was irrelevant to an explanation of successful organ transplantation.

\section{THE TWO-WAY PARADIGM}

\section{A. Human Observations}

A connection between the chimerism of hematolymphopoietic transplantation and the successful engraftment of whole organs was made with the discovery in 1992 of persistent donor leukocytes (microchimerism) up to 30 years postoperatively in the peripheral tissues or blood of human kidney, liver, and other organ recipients [4246] (Figure IC). The donor cells were few in number, requiring sensitive immunocytochemical and polymerase chain reaction (PCR) techniques for detection. Nevertheless, we were able to postulate that the donor-derived leukocytes constituted one limb of antagonistic but ultimately reciprocally attenuated or abrogated HVG (rejection) and GVH reactions $[42-47]$.

In this context, disruption of the leukocyte interaction by the host cytoablation used to prepare bone marrow recipients. but not the recipients of whole organs. was responsible for the disparities in the two different kinds of transplantation (Table 1). The canceiling effect of the two immunocyte populations under the conditions of postoperative immunosuppression used for organ transplantation explained the poor prognostic discrimination of human leukocyte antigen (HLA) matching as well as the rarity of GVHD after the engrattment of immunologically active organs such 

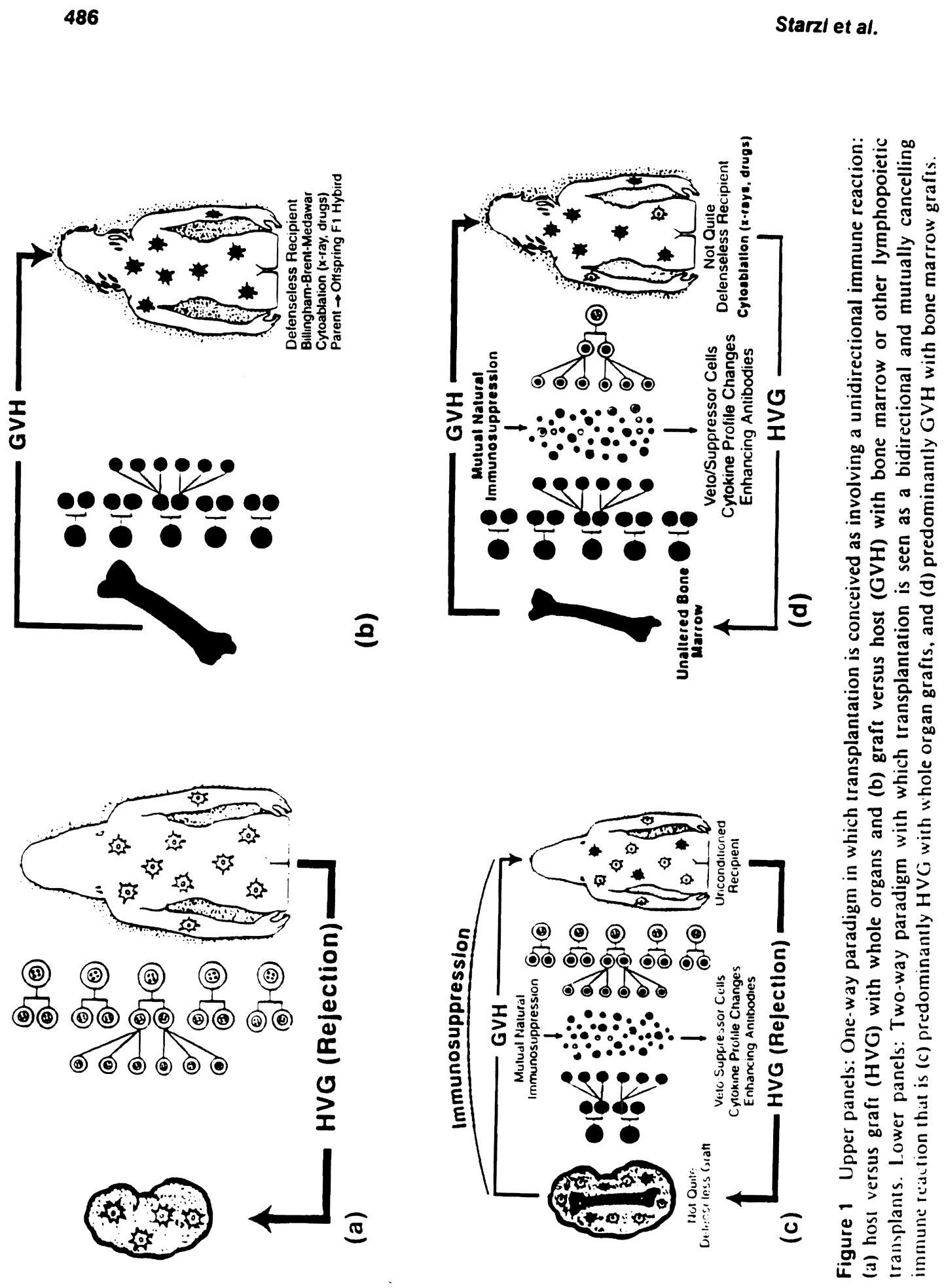
Table 1 Differences Between Conventional Bone Marrow and Organ Transplantation

\begin{tabular}{llll}
\hline Bone marrow & & & Organ \\
\hline Yes & $\leftarrow$ Recipient cytoablation" $\rightarrow$ & No \\
Critical & $\leftarrow$ MHC compatibility $\rightarrow$ & Not critical \\
GVHD & $\leftarrow$ Principal complication $\rightarrow$ & Rejection \\
Common & $\leftarrow$ Drug-free state $\rightarrow$ & Rare \\
Tolerance & $\leftarrow$ Term for success $\rightarrow$ & "Acceptance"b
\end{tabular}

All differences derive from this therapeutic step, which in effect establishes an unopposed GVH reaction in the bone marrow recipient, whose countervailing immune reaction is eliminated. MHC, major histocompatibility complex; GVHD. graft-versus-host disease. "Or "operational tolerance."

as the intestine and liver. It was obvious that the characteristic cycle of crisis and resolution, first observed in drug-immunosuppressed kidney recipients and most practically monitored by serial changes in allograft function [16], was the product of a dual immune reaction (Figure 2). At the same time as the peripheral migration of the donor cells, there was an influx of recipient cells that did not cause graft damage when adequate immunosuppression was given (Figure $1 C$ ) $[44,45,48-52]$. If transplantation was successful, both the allograft and the recipient became genetic composites.

It also was proposed that bone marrow and organ transplantation were, in fact, mirror images, resulting from the drastically different treatment strategies $[4,42]$. This contention has been supported by reports describing a trace residual population of recipient leukocytes in essentially all human bone marrow recipients,

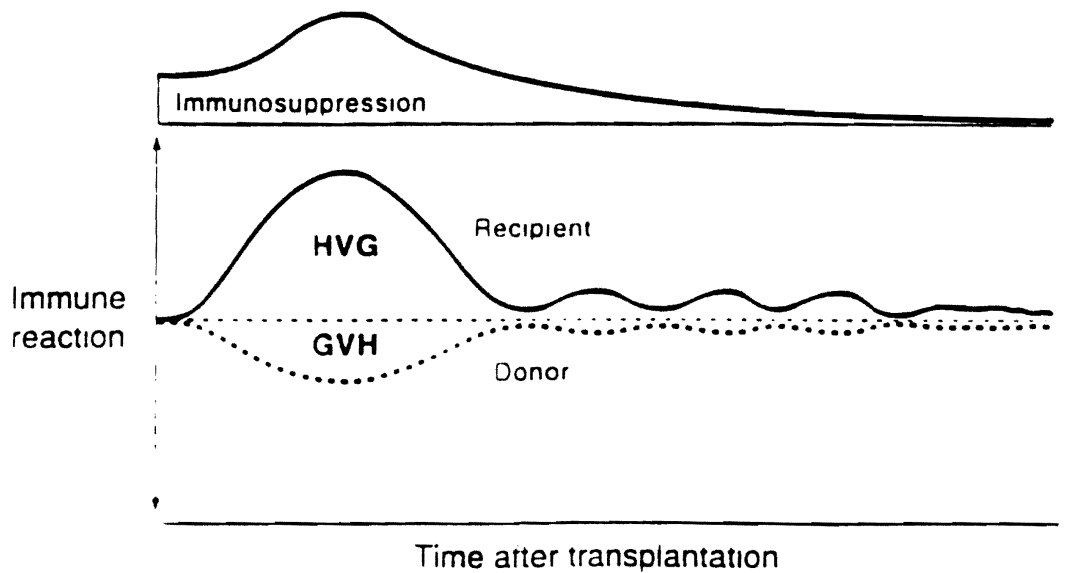

Figure 2 Contemporaneous host-versus-graft (HVG) and graft-versus-host (GVH) reactions in the two-way paradigm of transplantation immunology. After the initial interaction. the evolution of tolerance of each leukocvte population to the other is seen as a low-grade itımulatory state that may wax and wane rather than a deletional one. (By permission of Immunology rodav.) 
who previously were thought to have complete donor cell chimerism (Figure ID) $[53,54]$.

\section{B. Experimental Evidence}

The microchimerism following organ transplantation has been studied extensively in a variety of rat and mouse allograft models [55-69]. Although limited tissue or blood sampling of patients bearing organ allografts does not always reveal the microchimerism [44,70-73], the experimental studies have shown that the failure to find donor leukocytes in a long surviving organ allograft recipient simply reflects an inadequate search $[59,66,67]$. The cumulative evidence from the experimental studies has all but eliminated the alternative possibility that the microchimerism may be an effect rather than the cause of organ allograft acceptance $[74,75]$. The answer to this "chicken or egg first?" question [76] was the same as in historical investigations of florid chimerism [77-80].

Also in accord with classical studies, the quantity and lineage composition of the donor leukocytes contained within the transplanted rodent organs strongly influenced their survival in the recipient and determined whether the chimerism that they produced was associated with lethal GVHD or graft acceptance [66]. Nonparenchymal cells of the liver (the most tolerogenic whole organ) resembled bone marrow cell suspensions in that both contained higher numbers of immature leukocytes and cells of myeloid origin than the lymphocyte-rich and GVHD-prone intestinal allograft or allogenic lymph node or spleen cell suspensions [66].

Thus, the difference between the chimerism produced by classical bone marrow transplantation and that produced by the migratory leukocytes from whole organs has appeared to be largely semantic, dose-dependent, and influenced by the lineage profile of the "passenger leukocytes" contained in the organ allograft. In line with this conclusion, the changes following transplantation to noncytoablated rodent recipients of the hind limb with its rich bone marrow content are much the same as those after engraftment of visceral organs [81].

\section{The Role of Immunosuppression}

A protective umbrella of immunosuppression is usually needed for the survival of the minority population [66] (Figures IC and 2). However, this may be only a temporary requirement after outbred canine liver $[82]$ and kidney transplantation [83-86] and in rodent models too numerous to cite of liver, heart, lung, and kidney transplantation. Moreover, the permanent acceptance of liver allografts is possible with no treatment at all in a significant percentage of outbred pigs [87-90] and several rat strain $[91,92]$ and virtually all mouse strain combinations [59]. Mouse heart [59.93] and kidney allografts [94] are also accepted without the need for immunosuppression in a much more limited number of MHC disparate circumstances. In all of these animal models, the allograft passes through an acute selfresolving rejection on the way to tolerance. The tolerance induced by the organ variably extends to other donor tissues and organs $[59,66,91-95]$ despite the fact that antidonor reactivity determined with in vitro testing is almost invariably retained (split tolerance) $[66.96-98]$ or can be restored by the addition of the appro- 
priate cytokines to the cultures. Species-specific tolerogenic effects of the liver also have been demonstrated after hamster $\rightarrow$ rat xenotransplantation [99].

Organ tolerogenicity also occurs in humans, especially after liver transplantation [44], but at a slower and unpredictable pace. By October 1995, $12(28 \%)$ of our 42 longest surviving liver recipients (13-1/2 to 26 years post operative) had stopped their immunosuppressive drugs. The nearly equal cumulative duration of the 12 patients off immunosuppression (shaded) and under treatment (shown in black) is evident in Figure 3. At present, however, it is not possible to determine by immunological testing which patients can be weaned from therapy. In a more recent prospective trial [100] that now includes 95 patients [101], weaning was started $>5$ years post transplantation. In the first 80 cases, in $30 \%$ of the recipients, including some with proven microchimerism, rejection developed, necessitating resumption of maintenance immunosuppression (Figure 4). Thus, although many of the long surviving MHC mismatched cadaveric human liver recipients no longer need immunosuppression, some probably can never aspire to be drug-free. Even in such patients, however, the disseminated donor-derived leukocytes (and their companion organ) apparently can be maintained for a lifetime under continuous immunosuppression.

The same principles apply with less tolerogenic organs. Discontinuance of immunosuppression is thought to be more dangerous in nonhepatic recipients. Nevertheless, 5 of our 10 longest surviving living related kidney recipients (all treated before March 1964 [102]) have been off all immunosuppression for 3 to 30 years

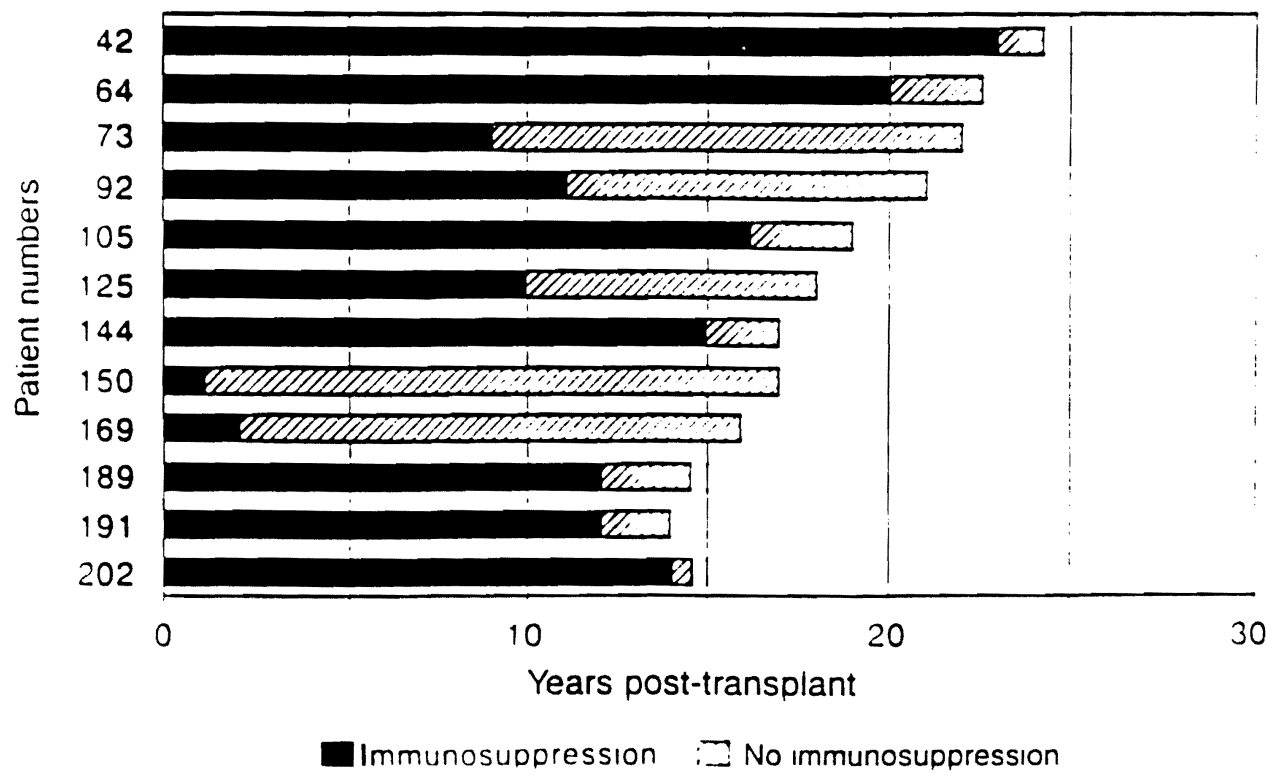

Figure 3 Time on and off of immunusuppression (gray) of 12 long surviving liver recipients who were receiving no drug treatment in October 1995 . Patients 150 and 169 stopped medication less than 2 years post transplantation because of noncompliance. The others were weaned because of complications of chronic immunosuppression. These 12 patients represent $28 \%$ ol the 42 in our total experience who have conunuousiy borne hepatic allogratts tor 15 to $25.5 / 6$ vears. 


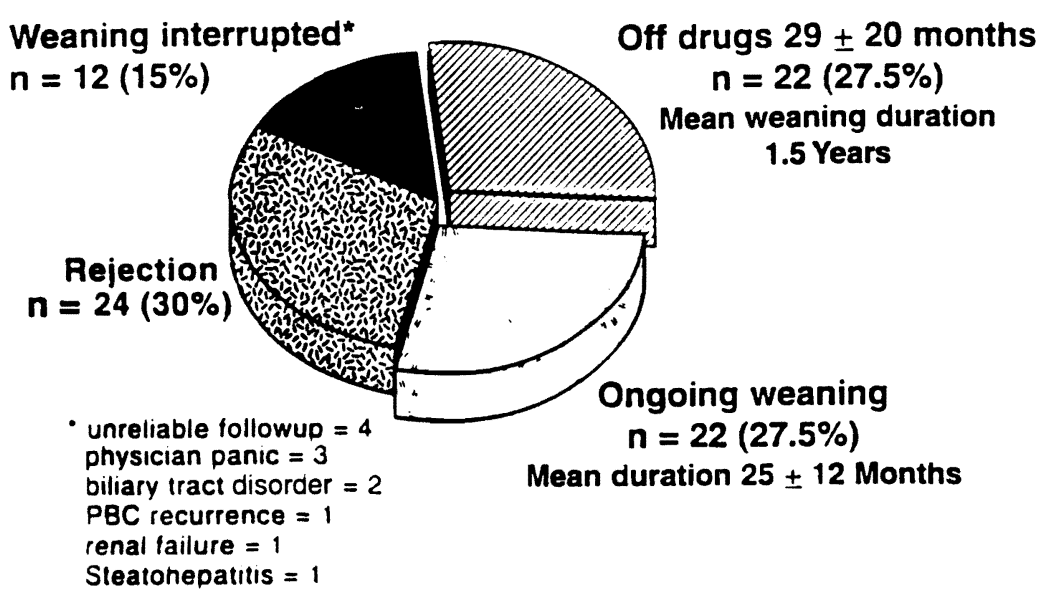

Figure 4 Summary of the first 80 liver recipients in a prospective weaning trial by the University of Pittsburgh Medical Center $(n=80)$. Note that more than half of the patients are completely off drugs or are on an uninterrupted schedule of drug reduction. The rate of weaning has been slowed from that used originally because of a $30 \%$ incidence of rejection (see text). There have been no patient or graft losses. Weaning was interrupted if noncompliance was detected or in the presence of intrinsic liver disease, including the reemergence of autoimmune disorders.

(Table 2). Patients 3 and 4, whose mixed lymphocyte reaction (MLR) test results showed a profoundly depressed reaction to donor and third-party targets before drug withdrawal [45], had prompt restoration of response to both in the drug-free state but with no evidence of rejection.

\section{The Stem Cell Question}

The persistence of multilineage donor cells in human organ recipient tissues for up to 30 years after transplantation has been construed as prima facie evidence of the presence of hematopoietic stem and precursor cells among the donor leukocytes that

Table 2 Discontinuance of Immunosuppression in Long-Term Living Related Kidney Recipients

\begin{tabular}{lcccc}
\hline Patient & Years post Tx & $\begin{array}{c}\text { Haplotype } \\
\text { mismatch }\end{array}$ & $\begin{array}{c}\text { Indication for } \\
\text { weaning }\end{array}$ & Years off drugs \\
\hline $1(\mathrm{KP})$ & 33 & 0 & $\mathrm{Nc}$ & 30 \\
$2(\mathrm{SM})^{\circ}$ & 32 & 1 & Comp & 15 \\
$3(\mathrm{JN})$ & 32 & 0 & $\mathrm{Nc}$ & 29 \\
$+(\mathrm{JW})^{\circ}$ & 32 & 2 & Comp & $3-1 / 2$ \\
$5(\mathrm{DS})^{\circ}$ & 33 & 1 & Comp & 3 \\
\hline
\end{tabular}

'These are 5 of the 16 longest functioning allogratts in the world.

rComp. complications: skin cancer, warts, intection. hypertension, obesitv, orthopedic problems: Nc. noncompliant.

These were children at the tume of transplantation 
migrate from the organ allografts $[103,104]$. This belied the widely held belief that hematolymphopoietic stem cells in adult mammalian life require a bone marrow microenvironment. In interdiction of this axiom, it has been shown that all hematolymphopoietic lineages in supralethally irradiated mice $(9.5 \mathrm{~Gy})$ can be reconstituted as efficiently as with bone marrow by the infusion of stem cells isolated from syngeneic adult mouse livers [105-107].

The contention that stem cells are present in the adult liver and in other organs (but in smaller numbers) has been upheld by direct experimentation. Irradiated rats can be reconstituted with the expedient of orthotopic liver transplantation just as reliably as with bone marrow [108]. Importantly, heterotopic heart transplantation had a therapeutic effect similar to that of $0.5 \times 10^{6}$ infused donor bone marrow cells or a large blood transfusion, allowing permanent hematopoietic reconstitution of occasional cardiac recipients and prolongation of survival of almost all other [108]. This occasional rescue is increased to nearly $100 \%$ by the post-cardiac transplantation administration of lisofylline (Murase et al., manuscript in preparation). This phosphatidic acid inhibitor facilitates bone marrow engraftment by suppressing hematopoiesis-inhibiting cytokines (tumor necrosis factor $\alpha$ [TNF- $\alpha$ ], TGF- $\beta$, macrophage inhibitory protein $1-\alpha$, platelet factor 4 , etc.) released in response to activation stimuli (interleukin I [IL-1], IL-8, lipopolysaccharide [LPS], platelet activating factor [PAF], cellular transformation) that are typical in the posttransplant period while not altering levels or activities of the myeloid progenitor cell promoting cytokines granulocyte colony-stimulating factor (G-CSF) and granulocyte macrophage colony-stimulating factor (GM-CSF) [109].

\section{UNIFICATION OF THE ONE-AND TWO-WAY PARADIGMS}

In the context of the two-way paradigm, the suppressor and veto cells, changes in cytokine profile, and enhancing antibodies seen in allograft recipients are tolerance effector mechanisms, secondary to the seminal event of donor/recipient leukocyte engagement (Figure $\mathrm{IC}$ and D). With this new mind-set, the vast reservoir of information obtained with reductionist in vitro and in vivo methods in efforts to elucidate the deeper meaning of tolerance can be brought to bear on problems of transplantation.

Many of the purest of such experiments have been one-way paradigmatic, showing the effects of exogenous or transgenic antigen or $T$ lymphocytes and other immune cell subpopulations. The intellectual adjustment required for application of such data to transplantation is envisioning the alterations in two immunocyte populations, each of which can modulate the other. In addition to a mutual antigen stimulus, the two-way paradigm implies an active self-protective effect $1 \mathrm{GVH}$ or HVG) of the coexisting arms that is particularly important if one cell population is outnumbered and if there is severe MHC disparity. This "defensive" mechanism of engraftment facilitation was first suggested by Mathe et al. $[110]$ and Vriesendorp $[111]$ and discussed subsequently by Gale and Reisner [112] and Plotnicky and Touraine [113] but only in connection with hematolymphopoietic reconstititution atter recipient cytoablation. 


\section{A. Leukocyte Subsets}

"T cell tolerance" has been the term used for successful experimental manipulations in a spectrum of highly controlled conditions. There has been much evidence, however, that the $\mathrm{T}$ lymphocytes are directed by specialized immune regulatory leukocytes of $T$ cell or unknown lineage (i.e., veto [114] and suppressor [115] cells). Burlingham et al. [116] have isolated a circulating donor leukocyte of unknown lineage in a tolerant human kidney recipient with such powerful veto function that a single cell can neutralize the in vitro activity of 10,000 recipient cytotoxic $T$ lymphocytes (CTLs).

The probability that professional antigen presenting cells (APCs) ultimately govern transplantation tolerance (discussed by Steinman, Inaba, and Austyn [117]) was raised by the invariably prominent presence of dendritic cells (DCs) in chimeric human $[42,44]$ and animal organ recipients $[56,59]$. Using culture techniques developed by Inaba et al. [118], donor-derived DC precursors have been propagated from disseminated locations in mouse recipients of spontaneously accepted liver allografts, admixed with recipient DCs, presumably undergoing the same changes $[104,119,120]$ (Figure 5). These immature DCs, which are phagocytic [121] and deficient in surface costimulatory molecule expression (B7 family) [122], have been shown to induce $\mathrm{T}$ cell hyporesponsiveness in vitro and to prolong organ allograft survival [123].

\section{B. Multimechanistic Hypotheses}

Such clues are intriguing, but it is unlikely that allograft acceptance can be fully comprehended from the results of studies of individual leukocyte phenotypes [47].

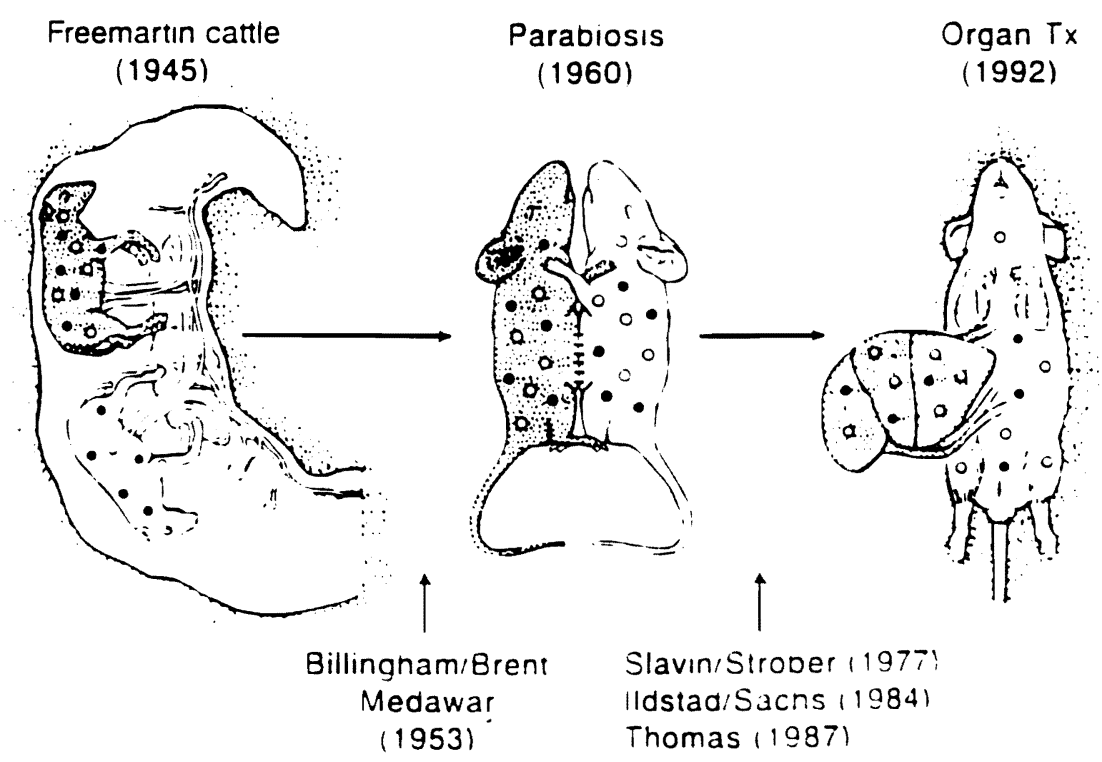

Figure 5 Cununuum of chimerism from observations of Ray Owen in treemartun cattle to the discoverv in 1992 of microchimerism in organ recipients. 
Instead, the events leading to this state suggest learning (cognitive) and intelligence functions of the immune system that are properties of the networks postulated to explain tolerance to nonliving antigens by Jerne [21], Coutinho [22], Cohen [23], and Waldmann et al. [124]. Network activity under the circumstances of transplantation presumably would be multimechanistically influenced by cytokines, immunoregulatory cells, antibodies, and other factors.

Such multimechanistic hypotheses have been advanced in the past in the context of the one-way paradigm [125-128], at first with little consideration of the far reaching implications of the two-signal theory articulated by Bretscher and Cohn [129] and extended by Jenkins et al. [130] and Schwartz [131]. After the concept of nonlethal clonal silencing was elaborated and experimentally supported by Nossal $[27,132]$, effector immunocytes could be envisioned as surviving in a quiescent, anergic, or activated state, or alternatively proceeding to apoptosis [133-135]. Considering the shifting details of signalling and response involved in the merger of two interactive and genetically controlled immune systems of the two-way paradigm, computer modeling based on known and experimentally verifiable events may be required to comprehend the total process.

\section{Is Acquired Tolerance Thymic?}

The role of the thymic versus peripheral mechanisms [136] in graft acceptance under clinical circumstances has been controversial. The prompt appearance of donor-derived leukocytes in the recipient thymus after organ transplantation was of particular interest because of the strikingly tolerogenic effect in rodents of intrathymic inoculation of donor leukocytes $[137,138]$. However, thymectomy in adult rates does not influence either the chimerism or spontaneous tolerance induced by liver transplantation [63]. Dejbakhsh-Jones et al. [139] have shown that after thymectomy and lethal irradiation in adult mice reconstituted with purified hematolymphopoietic stem cells, $\alpha \beta^{3} \mathrm{~T}$ cells developed no different ly than in control animals except for a reduced proportion in the spleen.

Between 1962 and 1965, 32 patients, including 24 who were part of a controlled randomized trial, underwent transthoracic thymectomy from 8 to 112 days (average 22) before renal transplantation from living related or unrelated donors. After $3-1 / 2$ to 7 years, no clinical differences were apparent between the thymectomized and control recipients, although there was a trend to better histopathological findings in the thymectomy group [140]. In 1992, comprehensive in vitro immunological studies of many of the remaining recipients and their donors did not reveal any distinguishing features of one cohort versus the other (Gene Shearer and Adriana Zeevi, unpublished observations). After 25 to 30 years, the thymectomized patients had no clinical advantage or disadvantage.

\section{The Parking Models}

Although parking experiments have been put to good use in transplantation research $[141,1+2]$, the altered (nonreactive) leukocytes that repopulate an organ during residency in the intermediary allogeneic host disqualify the graft's retransplantation for study of complex tolerance mechanisms. In addition. the leukocyte replacement during the parking period is not complete. Even at 1 year of residence in a tolerant 
recipient, $10 \%$ of the nonparenchymal cells (NPCs) remain donor, a proportion that is essentially fixed from day 100 onward [56]. Not surprisingly, the results after the second-stage procedure have been uninterpretable $[69,143]$.

In simpler experiments involving only the depletion of organ leukocytes by donor irradiation, both the tolerogenicity and antigenicity of heart [135] and liver allografts [68] are abrogated or weakened. Tolerogenicity can be restored by an infusion of donor strain splenocytes 24 hours before the organ is removed for transplantation [144]. The necessary presence of donor leukocytes for tolerogenicity also has been unequivocally shown with pancreatic islet transplantation into the thymus [137] and in several other related models.

\section{WHAT IS HUMAN TRANSPLANTATION TOLERANCE?}

Permanent drug-free graft acceptance after a course of immunosuppression usually is termed "operational tolerance" to distinguish it from the ostensibly pristine neonatal tolerance of Billingham, Brent, and Medawar [2,3]. However, Streilein has demonstrated not only how heterogeneous the outcome in the acquired neonatal tolerance model actually is, but how uncommon it is to achieve a state resembling complete donor-specific clonal deletion [145]. Alard et al. [146] have recently shown in these chimeric animals that the ability of donor-derived leukocytes to proliferate in response to a skin graft challenge was a more critical determinant of tolerance outcome than the baseline level of chimerism. This was only the latest evidence that transplantation tolerance is an active nondeletional process.

Is the ability of a human allograft recipient to discontinue immunosuppression successfully long after either organ or bone marrow transplantation fundamentally different from the gold standard tolerance that is so easy to produce with inbred rodent models? We do not think so. When we determined donor-leukocyte chimerism to be present up to 30 years post transplantation in our organ recipients, we realized that all examples of allograft "acceptance," whether immunosuppressiondependent or not, were variations on the theme originally described by Billingham, Brent, and Medawar [2,3].

With this finding, it was possible to define both success and failure after transplantation in a different way than before. Success "(whether described as) tolerance or graft acceptance [meant] that a characteristic lymphoid and dendritic cell chimerism had been introduced which may be stable either without further treatment, or only when continued immunosuppression is provided" [42]. Failure connoted a state in which "an unstable graft and its migrated cells may either be rejected or cause GVHD" [42]. It required no imagination to see the uninterrupted thread of chimerism from the observations by Owen [147] of natural tolerance in freemartin cattle to the donor-derived leukocytes found nearly a half century later in human and animal recipients of organ allografts. Between these brackets lay the rodent neonatal $[2,3]$, cytoablation-dependent $[7,8]$, parabiosis-induced [148], and more complicated "mixed chimerism" tolerance models [149-151] (Figure 5).

One of the lessons emphasized in our first $[42]$ and all subsequent reports of organ transplantation-associated chimerism was that the rapidly evolving drug-tree 
donor-specific tolerance induced with donor leukocytes in a few days in rodent models could not be extrapolated to unrealistic clinical expectations $[76,103]$. In clinical practice, the duration of mutual exposure of the two cell populations necessary permanently to prevent one of the response arms from destroying the other has been widely variable, as was illustrated by the liver transplantation weaning trials. Moreover, there has been no way, except by trial and error, to determine the amount of immunosuppression required during this period. There has not been evidence that increasing maintenance drug dosage above the requisite threshold level can accelerate the events leading to tolerance; it is likely that excessive therapy may prevent achievement of this objective.

Thus, immunosuppressive agents, which have diverse sites of action [152], do not cause tolerance, but rather permit it with variable success by allowing an alternative normal function of the immune system to be expressed. Chimerism and the derivative state of tolerance are almost contemporaneous in numerous rodent models of liver transplantation (Figure 6). In contrast, the cause (chimerism) and the effect (tolerance) are separated by months or years when liver transplantation is performed in outbred animals and humans (Figure 6), no matter what the means of immunosuppression. In many cases, the desired drug-free end point may never be reached. Chimerism (and its companion allograft) can nevertheless be maintained for the lifetime of such patients under continuous immunosuppression.

The folly of using results obtained with rodent models to guide clinical treatment decisions is self-evident. It also is obvious that neither the presence nor the quantity of donor leukocyte chimerism can be used per se in planning drug weaning protocols for patients.

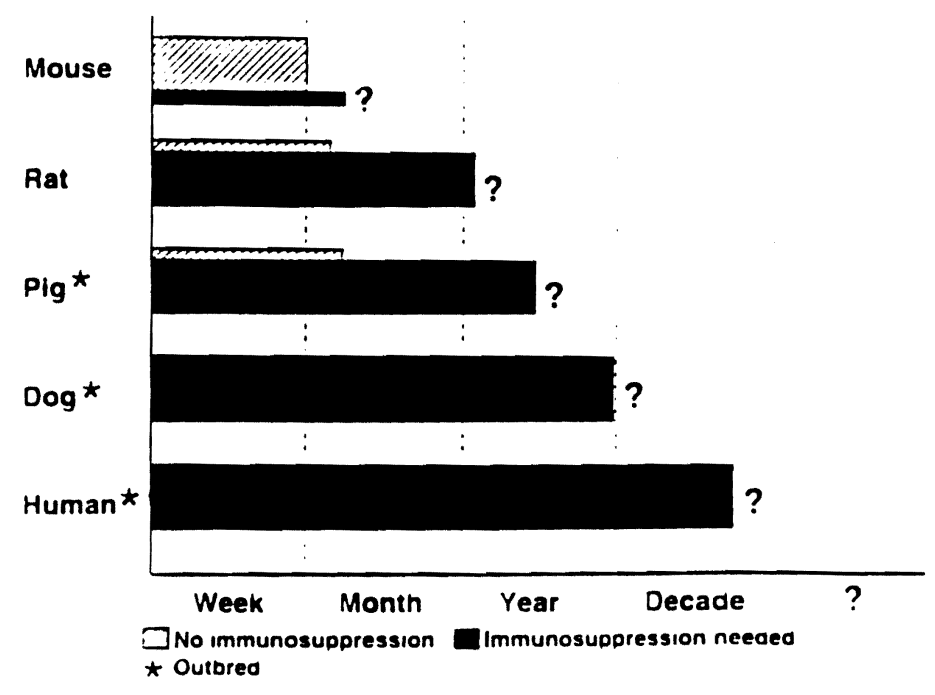

Figure 6 Time between cause (chimerism) and effect (donor-specific tolerance) after liver allotransplantation in different species. Note that immunosuppression is not universallv required in three of the five species shown. (By permission of Immunology Todav.) 


\section{THE GENETIC CONTROL OF TOLERANCE}

It would be equally absurd to believe that the events after transplantation, including the development of tolerance to alloantigens, are not under genetic control. This genetic framework has been too well worked out during the last 40 years to warrant extensive citation. However, most of the evidence of a precision effect of MHC on the outcome of organ transplantation in large mammals has been obtained under conditions of a perfect or near-perfect donor-recipient compatibility with surprisingly little fall-off in survival expectations of human organ recipients at various lesser levels of mismatching, no matter how extreme the incompatibility [153-157]. With bone marrow transplantation, an unambiguous demonstration of the MHC effect has depended on simulation of the immunologically defenseless ("one-way") neonatal tolerance conditions of Billingham, Brent, and Medawar [2,3] with recipient cytoablation $[33-37,157,158]$ or on breeding (e.g., the F1 hybrid preparations). Under all other circumstances, the results after transplantation, all the way from humans to mouse [59] and rat models [65,159], have not been congruent with the predications from genetic analyses.

The two-way paradigm explains why. For all practical purposes, the one constant factor for induction of lasting transplantation tolerance has been chimerism, the effects of which far exceed in strength and complexity the mere presence of nonliving donor antigen. Consequently, successful organ transplantation requires conditions that allow assimilation of the fragment of the donor immunological system introduced with the allograft into the preexisting recipient network, and vice versa. The subsequent reciprocal modulation of the large and the small immunological apparatus is determined within feasibility boundaries that are genetically proscribed for each.

In his recent review of two books on the history of immunology $[160,161]$, Rosen remarked, "Having solved the problem of the molecular basis of specificity, immunology reached the end of its history" [162]. However, all properties of the immune system cannot be explained with the concept of a genetically "hard-wired self." Tauber has suggested that such a bias is derived from a Western individualistic philosophy of how humans relate to the world [28]. In our view, MHC did not evolve to permit immunological segregation but rather to meet the need of populations, not individuals, for immunological flexibility. In this context, the genetic issue is not self versus nonself so much as the ability of the population to adapt to change and the survival need for such maneuverability. Allograft rejection was, of course, an unforeseen by-product, and transplantation of surgically revascularized allografts was, in essence, the production and then control of an organ-specific autoimmune disease. Thus, contrary to Burnet's concern [29], there were no biological rules that prohibited chimerism or successful organ transplantation.

\section{THERAPEUTIC IMPLICATIONS}

The two-way paradigm allows predictions about what can (and cannot) be accomplished with tolerance inducing strategies, all of which are attempts to alter the donor/recipient leukocyte interaction. It has been established that when both immunocyte populations are competent, and when immunosuppression is delivered to the 
two arms equally, the microchimerism produced by organ transplantation can be greatly augmented by the coadministration of $3-6 \times 10^{8} / \mathrm{kg}$ unmodified donor bone marrow cells without a significant risk of GVHD [163]. The presence of donor deoxyribonucleic acid (DNA) in the myeloid and erythroid colonies generated from recipients' peripheral blood mononuclear cells (PBMCs) by using standard clonal hematopoietic progenitor cell assays provided unequivocal evidence of engraftment [164]. These findings have been confirmed and extended by Garcia Morales et al. [165], using innovative clonal hematopoietic progenitor cells assays.

Despite the increase of persistent chimerism to levels many times higher than that in control patients neither the timing, severity, nor frequency of acute rejection has been different than in non-marrow-augmented control patients [163-165] (Figure 7). It had not been anticipated that these endpoints would be altered. The hypotheses being tested are, first, that the threat of chronic organ rejection will be reduced, and, second, that the frequency of ultimate drug independence can be increased by achieving a higher persistent level of chimerism. An efficacy evaluation is expected to take 5 to 10 years, roughly the same time frame (Figure 6) delineated by three decades of clinical experience with $\mathrm{MHC}$-incompatible liver and bone marrow transplantation [103].

The administration of colony stimulating hematolymphopoietic growth factors (e.g., GM-CSF) or drugs like lisofylline (discussed earlier) is predicted to be without significant risk of GVHD if such chimerism augmenting treatment is imposed on both cell populations equally. In contrast, procedures that alter only one of the interacting arms must be approached with caution, as exemplified by the historical experience with GVHD after cytoablation and bone marrow transplantation. When the converse tactic of leukocyte- or T cell-specific depletion of intestinal

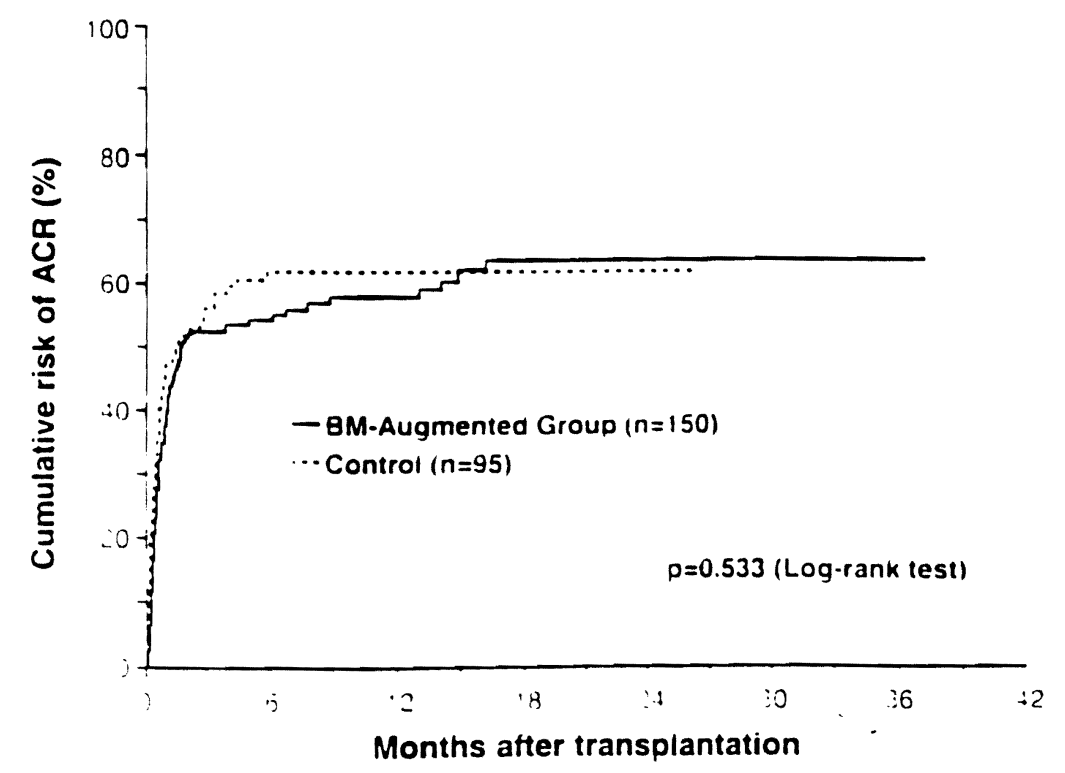

Figure 7 Cumulative incidence of rejection in bone marrow-augmented and -nonaugmented organ allogratt recipients. 
allografts was attempted in the 1980s as GVHD prophylaxis, in virtually every bowel recipient who survived the transplantation lethal Epstein-Barr virus-associated B cell lymphomas developed [52].

The highest priority in transplantation today is the clinical development of xenografting techniques. Although the interspecies activation of complement may be preventable with the creation of transgenic or otherwise altered animal donors, it is naive to believe that the success of xenotransplantation procedures will not involve the manipulation and control of the same bidirectional immune reactions as with allografts and the ultimate establishment of stable chimerism.

\section{CONCLUSION}

The unwarranted assumption that stem cell-driven hematolymphopoietic chimerism was irrelevant to successful whole organ transpiantation as currently practiced led to alternative inadequate explanations of organ allograft acceptance, clouded the meaning of successful bone marrow transplantation, and precluded for more than three decades the development of a cardinal principle of transplantation. Recognition of this error and incorporation of the chimerism factor into a two-way paradigm have allowed previous enigmas of organ as well as bone marrow engraftment to be explained and should allow the vast foundation of basic immunology to be more meaningfully exploited in transplantation. In turn, experimental examination of the mechanisms of the two-way immune interaction implicit in this concept may further elucidate the meaning of self/nonself discrimination.

\section{REFERENCES}

1. M Cohn. The wisdom of hindsight. Annu Rev Immunology 12:1-62, 1994.

2. RE Billingham, L Brent, PB Medawar. "Actively acquired tolerance" of foreign cells. Nature 172:603-606, 1953.

3. R Billingham, L Brent, $P$ Medawar. Quantitative studies on tissue transplantation immunity. III. Actively acquired tolerance. Philos Trans R Soc Lond (Biol) 239:357412, 1956.

4. TE Starzl, AJ Demetris. Transplantation milestones: Viewed with one- and two-way paradigms of tolerance. JAMA 273:876-879, 1995.

5. JA Mannick, HL Lochte, CA Ashley, ED Thomas, JW Ferrebee. A functioning kidney homotransplant in the dog. Surgery 46:821-828. 1959.

6. DM Hume, BT Jackson, CF Zukoski, HM Lee, HM Kauffman, RH Egdahl. The homotransplantation of kidneys and of fetal liver and spleen after total body irradiation. Ann Surg 152:354-373, 1960.

7. JM Main, RT Prehn. Successful skin homografts after the administration of high dosage $X$ radiation and homologous bone marrow. J Natl Cancer Inst 15:1023-1029. 1955.

8. JJ Trentin. Mortality and skin transplantibility in $\mathrm{X}$-irradiated mice recetving isologous or heterologous bone marrow. Proc Soc Exp Biol Med 92:688-693, 1956.

9. R Billingham. L Brent. A simple method for inducing tolerance of skin homogralts in mice. Trans Bull 4:67-71, 1957

10. I1 Simonsen. The impact on the developing embrvo and newhorn anmal of adult homologous cells. Acta Pathol Microbiol Scand $4(1): 4 \times()-5(0), 1957$. 
11. R Billingham, L Brent. Quantitative studies on transplantation immunity. IV. Induction of tolerance in newborn mice and studies on the phenomenon of runt disease. Philos Trans R Soc Lond (Biol) 242:439-477, 1959.

12. JP Merrill, JE Murray, JH Harrison, EA Friedman, JB Dealy Jr., GJ Dammin. Successful homotransplantation of the kidney between non-identical twins. N Engl J Med 262:1251-1260, 1960.

13. J Hamburger, J Vaysse, J Crosnier, J Auvert, CL Lalanne, J Hopper Jr. Renal homotransplantation in man after radiation of the recipient. Am J Med 32:854-871, 1962.

14. R Kuss, M Legrain, G Mathe, R Nedey, M Camey. Homologous human kidney transplantation: Experience with six patients. Postgrad Med J 38:528-531, 1962.

15. JE Murray, JP Merrill, JH Harrison, RE Wilson, GJ Dammin. Prolonged survival of human-kidney homografts by immunosuppressive drug therapy. $\mathrm{N}$ Engl J Med 268: 1315-1323, 1963.

16. TE Starzl, TL Marchioro, WR Waddell. The reversal of rejection in human renal homografts with subsequent development of homograft tolerance. Surg Gynecol Obstet 117:385-395, 1963.

17. DM Hume, JH Magee, HM Kaufmann Jr., MS Rittenbury, GR Prout. Renal homotransplantation in man in modified recipients. Ann Surg 158:642-643, 1963.

18. MFA Woodruff, JS Robson, B Nolan, AT Lambie, TI Wilson, JG Clark. Homotransplantation of kidney in patients treated by preoperative local irradiation and postoperative in administration of an antimetabolite (imuran). Lancet 2:675-682, 1963.

19. M Simonsen. On the acquisition of tolerance by adult cells. Ann NY Acad Sci 87:382$390,1960$.

20. D Michie, MFA Woodruff, IM Zeiss. An investigation of immunological tolerance based on chimera analysis. Immunology 4:413-424, 1961.

21. NK Jerne. Idiotypic networks and other preconceived ideas. Immunol Rev. 79:5-24, 1984.

22. A Coutinho. Beyond clonal selection and network. Immunol Rev 110:63-87, 1989.

23. IR Cohen. The cognitive paradigm and the immunological homunculus. Immunol Today 13:490-494, 1992.

24. M Simonsen. Graft versus host reactions: Their natural history, and applicability as tools of research. Prog Allergy 6:349-467, 1962.

25. KF Schaffner. Theory change in immunology. Part I. Extended theories and scientific progress. Theor Med 13:175-189, 1992.

26. KF Schaffner. Theory change in immunology. I1. The clonal selection theory. Theor Med 13:191-216, 1992.

27. GJV Nossal. Cellular mechanisms of immunologic tolerance. Annu Rev Immunol 1: 33-62, 1983.

28. Al Tauber. The Immune Self: Theory or Metaphor? Cambridge: Cambridge University Press, 1994.

29. FM Burnet. The new approach to immunology. N Engl J Med 264:24-34, 1961.

30. PB Medawar. The behavior and fate of skin autografts and skin homografts in rabbits. J Anat 78:176-199, 1944.

31. F Bach, $\mathrm{K}$ Hirschhorn. Lymphocyte interaction: A potential histocompatibility test in vitro. Science 143:813-814, 1964.

32. B Bain, MR Vas, L Lowenstein. The development of large immature mononuclear cells in mixed leukocyte cultures. Blood 23:108-116, 1964.

33. ( Mathe, JL Amiel, L Schwarzenberg, A Cattan, M Schneider. Haematopoietic chi. mera in man atter allogenic (homologous) bone marrow (ransplantation. Br Med J 2: 1633-1635, 1963.

34. RA Ciatli, HJ Meuwissen. HD Allen, R Hong, RA Good. Immunological reconstituilon of sex-linked lymphopenic immunological deficiency. Lancet 2:1366-1369. 1968. 
35. FH Bach, RJ Albertini, P Joo, JL Anderson, MM Bortin. Bone-marrow transplantation in a patient with the Wiskott-Aldrich syndrome. Lancet 2:1364-1366, 1968.

36. ED Thomas. Allogeneic marrow grafting: A story of man and dog. In: Terasaki PI, ed. History of Transplantation: Thirty-Five Recollections. Los Angeles: UCLA Tissue Typing Laboratory, 1991, pp 379-393.

37. DW van Bekkum. Bone marrow transplantation: A story of stem cells. In: Terasaki PI, ed. History of Transplantation: Thirty-Five Recollections. Los Angeles: UCLA Tissue Typing Laboratory, 1991, pp 395-434.

38. DE Harrison. Competitive repopulation in unirradiated normal recipients. Blood 81 : 2473-2474, 1993.

39. T Mariani, C Martinez, JM Smith, RA Good. Induction of immunological tolerance to male skin isografts in female mice subsequent to neonatal period. Proc Soc Exp Biol Med 101:596-599, 1959.

40. L Brent, G Gowland. Induction of tolerance of skin homografts in immunologically competent mice. Nature 196:1298-1301, 1962.

41. FM Stewart, RB Crittenden, PA Lowry, S Pearson-White, PJ Quesenberry. Longterm engraftment of normal and post-5-fluorouracil murine marrow into normal nonmyeloablated mice. Blood 81:2566-2571, 1993.

42. TE Starzl, AJ Demetris, N Murase, S Ildstad, C Ricordi, M Trucco. Cell migration, chimerism, and graft acceptance. Lancet 339:1579-1582, 1992.

43. TE Starzl, AJ Demetris, M Trucco, H Ramos, A Zeevi, WA Rudert, M Kocova, C Ricordi, S Ildstad, N Murase. Systemic chimerism in human female recipients of male livers. Lancet 340:876-877, 1992.

44. TE Starzl, AJ Demetris, M Trucco, N Murase, C Ricordi, S Ildstad, H Ramos, S Todo, A Tzakis, JJ Fung, M Nalesnik, WA Rudert, M Kocova. Cell migration and chimerism after whole organ transplantation: The basis of graft acceptance. Hepatology 17:1127-1152, 1993

45. TE Starzl, AJ Demetris, M Trucco, A Zeevi, H Ramos, P Terasaki, WA Rudert, $M$ Kocova, C Ricordi, S Ildstad, N Murase. Chimerism and donor specific nonreactivity 27 to 29 years after kidney allotransplantation. Transplantation 55:1272-1277, 1993.

46. TE Starzl, AJ Demetris, M Trucco, S Ricordi, S Ildstad, P Terasaki, N Murase, RS Kendall, M Kocova, WA Rudert, A Zeevi, D Van Thiel. Chimerism after liver transplantation for type IV glycogen storage disease and Type I Gaucher's disease. $N$ Engl J Med 328:745-749, 1993.

47. AJ Demetris, N Murase, AS Rao, TE Starzl. The role of passenger leukocytes in rejection and "tolerance" after solid organ transplantation: A potential explanation of a paradox. In: JL Touraine, ed. Rejection and Tolerance, vol 25. Dordrecht. The Netherlands: Kluwer Academic, 1994, pp 325-392.

48. N Kashiwagi, KA Porter, I Penn, L Brettschneider. TE Starzl. Studies of homograft sex and of gamma globulin phenotypes after orthotopic homotransplantation of the human liver. Surg Forum 20:374-376, 1969.

49. KA Porter. Pathology of the orthotopic homograft and heterograft. In: TE Starzl, ed. Experience in Hepatic Transplantation. Philadelphia: WB Saunders, 1969, pp 464465.

50. N Murase, AJ Demetris, T Matsuzaki, A Yagihasi. S Todo. J Fung, TE Starzl. Long survival in rats atter multivisceral versus isolated small bowel allotransplantation under FK 506. Surgery 110:87-98, 1991.

51. Y Iwaki. TE Starzl. A Yagihashi. S Taniwaki. $K$ Abu-Elmagd, A Tzakis, J Fung, $S$ Todo. Replacement of donor lymphoid tissue in human small bowel transplants under FK 506 immunosuppression. Lancet 337:818-819. 1991.

52. TE Starzl, S Todo. A Tzakis, $M$ Alessiani, A Casavilla, $K$ Abu-Elmagd, JJ Fung. The many taces of multivisceral transplantation. Surg Gynecol Obstet 172:335-344, 1991. 
53. D Przepiorka, ED Thomas, DM Durham, L Fisher. Use of a probe to repeat sequence of the $\mathrm{Y}$ chromosome for detection of host cells in peripheral blood of bone marrow transplant recipients. Am J Clin Pathol 95:201-206, 1991.

54. M Wessman, S Popp, T Ruutu, L Volin, T Cremer, S Knuutila. Detection of residual host cells after bone marrow transplantation using non-isotopic in situ hyubridization and karyotype analysis. Bone Marrow Transplant 11:279-284, 1993.

55. AJ Demetris, N Murase, TE Starzl. Donor dendritic cells after liver and heart allotransplantation under short-term immunosuppression. Lancet 339:1611, 1992.

56. AJ Demetris, N Murase, S Fujisaki, JJ Fung, AS Rao, TE Starzl. Hematolymphoid cell trafficking, microchimerism, and GVHD reactions after liver, bone marrow, and heart transplantation. Transplant Proc 25:3337-3344, 1993.

57. V Sriwatanawongsa, HFFS Davies, IGM Brons, R Aspinall, S Thiru, NV Jamieson, RY Calne. Continued presence of donor leukocytes in recipients of liver grafts. Transplant Proc 25:371-372, 1993.

58. V Sriwatanawongsa, HFFS Davies, IGM Brons, DJG White, NV Jamieson, RY Calne. Conditions required for donor passenger leukocytes in the induction of tolerance of rat liver grafts. Transplant Proc 25:2855, 1993.

59. S Qian, AJ Demetris, N Murase, AS Rao, JJ Fung, TE Starzl. Murine liver allograft transplantation: Tolerance and donor cell chimerism. Hepatology 19:916-924, 1994.

60. R Lord, S Goto, E Kobayashi, N Kamada, M Sunagawa. Detection of membranebound and soluble MHC class I antigen from donor migrating cells following rat liver transplantation. Transplant Immunol 2:94-98, 1994.

61. Y Masaki, A Hirasawa, S Okuyama, G Tsujimoto, M Iwaya, XK Li, Y Yokoi, S Nakamura, S Baba, M Miyamoto, M Hara, K Shibata, Y Koga, H Amemiya, H Kimura. Microchimerism and heart allograft acceptance. Transplant Proc 27:148-150, 1994.

62. H Tashiro, Y Fukuda, A Kimura, S Hoshino, $H$ Ito, K Dohi. Assessment of microchimerism in rat liver transplantation by polymerase chain reaction. Heptatology 23:828834, 1996.

63. E Kobayashi, N Kamada, L Delriviere, R Lord, S Goto, NI Walker. Migration of donor cells into the thymus is not essential for induction and maintenance of systemic tolerance after liver transplantation in the rat. Immunology 84:333-336. 1995.

64. N Murase, AJ Demetris, J Woo, T Furuya, M Nalesnik, M Tanabe, S Todo, TE Starzl. Lymphocyte traffic and graft-versus-host disease after fully allogeneic small bowel transplantation. Transplant Proc 23:3246-3247, 1991.

65. N Murase, AJ Demetris, J Woo, M Tanabe, T Furuya, S Todo, TE Starzl. Graft versus host disease (GVHD) after BN to LEW compared to LEW to BN rat intestinal transplantation under FK 506. Transplantation 55:1-7, 1993.

66. N Murase, TE Starzl, M Tanabe, S Fujisaki, H Miyazawa, Q Ye, CP Delaney, JJ Fung, AJ Demetris. Variable chimerism, graft versus host disease, and tolerance after different kinds of cell and whole organ transplantation from Lewis to Brown-Norway rats. Transplantation 60:158-171, 1995.

67. N Murase, AJ Demetris, AC Tsamandas, Q Ye. TE Starzl. Heterogenous distribution of chimerism produced by rat organ and bone marrow allotransplantation. Transplantation 61:1126-1131, 1996.

68. J Sun, GW McCaughan, ND Gallagher, AGR Sheil. GA Bishop. Deletion of spontaneous rat liver allograft acceptance by donor irradiation. Transplantation 60:233-236. 1995.

69. V Sriwatanawongsa, HFFS Davies. RY Calne. The essentual roles of parenchymal tissues and passenger leukocytes in the tolerance induced by liver gratting in rats. Nature Med 1:428-432, 1995.

-0. C Suberbielle, S Caillat-Zucman. C Legendre, ('Bodemer, LH Noel, H Kreis. JF 
Bach. Peripheral microchimerism in long-term cadaveric kidney allograft recipients. Lancet 343:1468-1469, 1994.

71. J Hundrieser, M Hisanaga, K Boker, G Raddatz, A Frederlau, B Nashan, R Pichlmayr, HJ Schlitt. Long-term chimerism in liver transplantation: No evidence for immunological relevance but requirement for graft persistence. Transplant Proc 27:216$218,1995$.

72. $M$ Hisanaga, $J$ Hundrieser, $K$ Boker, $K$ Uthoff, G Raddatz, $T$ Wahlers, $K$ Wonigeit, R Pichlmayr, HJ Schlitt. Development, stability and clinical correlations of allogeneic microchimerism after solid organ transplantation. Transplantation 61:40-45, 1996.

73. HJ Schlitt, J Hundrieser, M Hisanaga, K Uthoff, M Karck, T Wahlers, K Wonigeit, $R$ Pichlmayr. Patterns of donor-type microchimerism after heart transplantation. Lancet 343:1469-1471, 1994.

74. R Calne, H Davies. Organ graft tolerance: The liver effect. Lancet 343:67-68, 1994.

75. A Bushell, TC Pearson, PJ Morris, $\mathrm{KJ}$ Wood. Donor recipient microchimerism is not required for tolerance induction following recipient pretreatment with donor-specific transfusion and anti-CD4 antibody. Transplantation 59:1367-1371, 1995.

76. TE Starzl, AJ Demetris, N Murase, M Trucco, AW Thomson, AS Rao. The lost chord: Microchimerism and allograft survival. Immunol Today 17:577-584, 1996.

77. PS Russell. Modification of runt disease in mice by various means. In: GEW Wolstenholme, MP Cameron, eds. CIBA Foundation Symposium on Transplantation. Boston: Little, Brown, 1962, pp 350-383.

78. DM Lubaroff, WK Silvers. The abolition of tolerance of skin homografts in rats with isoantiserum. J Immunol 104:1236-1241, 1970.

79. Y Sharabi, VS Abraham, M Sykes, DH Sachs. Mixed allogeneic chimeras prepared by non-myeloablative regimen: Requirements for chimerism to maintain tolerance. Bone Marrow Transplant 9:191-197, 1992.

80. SM Wren, ML Hronakes, ST Ildstad. The requirement for allogeneic chimerism for second transfer of tolerance from mixed allogeneic chimeras $(A+B \rightarrow A)$ to secondary recipients. Transplantation 54:1031-1040, 1992.

81. M Talmor, RM Steinman, MA Codner, M Chen, AD Harper. Bone marrow-derived chimerism in non-irradiated, cyclosporin-treated rats receiving microvascularized limb transplants: Evidence for donor-derived dendritic cells in recipient lymphoid tissues. Immunology 86:448-455, 1995.

82. TE Starzl, TL Marchioro, KA Porter, PD Taylor, TD Faris, TJ Herrmann, CJ Hlad, WR Waddell. Factors determining short- and long-term survival after orthotopic liver homotransplantation in the dog. Surgery 58:131-155, 1965.

83. JC Pierce, RL Varco. Effects of long term 6-mercaptopurine treatment upon kidney homotransplants in dogs. Surgery 54:124-135, 1963.

84. CF Zukowski, JM Callaway. Adult tolerance induced by 6 -methyl mercaptopurine to canine renal homografts. Nature (London) 198:706-707, 1963.

85. JE Murray, AGR Sheil, R Moseley, PR Knight, JD McGavic, GJ Dammin. Analysis of mechanism of immunosuppressive drugs in renal homotransplantation. Ann Surg 160:449-473, 1964.

86. TE Starzl. Host-graft adaptation. In: Experience In Renal Transplantation. Philadelphia: WB Saunders. 1964, pp 164-170.

87. G Cordier, H Garnier, JP Clot, P Camplez. JP Gorin, PH Clot, JP Rassinier, M Nizza, R Levy. La greffe de foie orthotopique chez le porc. Mem Acad Chir (Paris) 92:799-802, 1966.

88. JH Peacock. J Terblanche. Orthotopic homotransplantation of the liver in the pig. In: Read AE, ed. The Liver. London: Butterworth. 1967. pp 333-336.

89. RY Calne. HJO White, DE Yoffa, RR Maginn, RM Binns, JR Samuel, VP Molina. Observations of orthotopic liver transplantation in the pig. Br Med J 2:478-480. 1967. 
90. TE Starzl. Experience in Hepatic Transplantation: Rejection in Unmodified Animals. Philadelphia: WB Saunders, 1969, pp 176-192.

91. FA Zimmermann, GW Butcher, HFFS Davies, G Brons, N Kamada, O Turel. Techniques for orthotopic liver transplantation in the rat and some studies of the immunologic responses to fully allogeneic liver grafts. Transplant Proc 11:571-577, 1979.

92. N Kamada, HFFS Davies, B Roser. Reversal of transplantation immunity by liver grafting. Nature 292:840-842, 1981.

93. RJ Corry, HJ Winn, PS Russell. Primary vascularized allografts of hearts in mice: The role of H-2D, H-2K and non-H-2 antigens in rejection. Transplantation 16:343350, 1973.

94. PS Russell, CM Chase, RB Colvin, JMD Plate. Kidney transplants in mice: An analysis of the immune status of mice bearing long-term $\mathrm{H}-2$ incompatible transplants. J Exp Med 147:1449-1468, 1978.

95. RY Calne, RA Sells, Pena Jr., DR Davis, PR Millard, BM Herbertson, RM Binns, DAL Davies. Induction of immunological tolerance by porcine liver allografts. Nature 223:472-474, 1969.

96. N Murase, DG Kim, S Todo, DV Cramer, JJ Fung, TE Starzl. FK 506 suppression of heart and liver allograft rejection. 11. The induction of graft acceptance in rat. Transplantation 50:739-744, 1990.

97. U Dahmen, S Qian, AS Rao, AJ Demetris, F Fu, H Sun, L Gao, JJ Fung, TE Starzl. Split tolerance induced by orthotopic liver transplantation in mice. Transplantation 58:1-8, 1994.

98. N Kamada, ed. Systemic tolerance induced by liver transplantation. In Experimental Liver Transplantation. Boca Raton, FL:CRC Press, 1988, pp 67-80.

99. LA Valdivia, AJ Demetris, JJ Fung, S Celli, N Murase, TE Starzl. Successful hamster to rat liver xenotransplantation under FK506 immunosuppression induces unresponsiveness to hamster heart and skin. Transplantation 55:659-661, 1993.

100. HC Ramos, J Reyes, K Abu-Elmagd, A Zeevi, N Reinsmoen, A Tzakis, AJ Demetris, JJ Fung, B Flynn, J McMichael. F Ebert, TE Starzl. Weaning of immunosuppression in long term liver transplant recipients. Transplantation 59:212-217, 1995.

101. GV Mazariegos, J Reyes, I Marino, B Flynn. W Irish, J McMichael, JJ Fung, TE Starzl. Long-term follow-up of weaning of immunosuppression in liver transplant recipients. Transplantation 63:243-249, 1997.

102. GV Mazariegos, H Ramos, R Shapiro, A Zeevi, JJ Fung, TE Starzl. Weaning of immunosuppression in long-term recipients of living related renal transplants: $A$ preliminary study. Transplant Proc 27:207-209, 1995.

103. TE Starzl, AJ Demetris, N Murase, AW Thomson, M Trucco, C Ricordi. Donor cell chimerism permitted by immunosuppressive drugs: A new view of organ transplantation. Immunol Today 14:326-332, 1993.

104. AW Thomson, L Lu, N Murase, AJ Demetris, AS Rao, TE Starzl. Microchimerism. dendritic cell progenitors and transplantation tolerance. Stem Cells 13:622-639. 1995.

105. EF Hays, DM Hays, DW Gulde. Hemopoietic stem cells in mouse liver. Exp Hematol 6:18-27, 1978.

106. T Decker, ML Lohmann-Matthes, $M$ Baccarini. Liver-associated macrophage precursor cells proliferate under impairment of regular hemopoiesis. Eur J Immunol 18:697703. 1988.

107. H Taniguchi. T Toyoshima, K Fukao. H Nakauchi. Presence of hematopoietic stem cells in the adult liver. Nature Nled 2:198-203. 1996.

108. V Murase. TE Starzl, Q Ye, A rsamandas, AW Thomson. AS Rao. AJ Demetris. Multilineage hematopoietic reconstutution of supralethally irradiated rats by syngeneic whole organ transplantation with particular reterence to the liver. Transplantation ol: $1-3.1996$ 
109. JW Singer, SL Burstein, GC Rice, WP Gordon, JA Bianco. Inhibitors of intracellular phosphatic acid production: Novel therapeutics with broad clinical applications. Exp Opin Invest Drugs 3(6):631-643, 1994.

110. G Mathe, JL Amiel, L Schwarzenberg, J Choay, P Trolard, M Schneider, M Hayat, JR Schlumberger, CI Jasmin. Bone marrow graft in man after conditioning by antilymphocytic serum. Br Med J 2:131-136, 1970.

111. HM Vriesendorp. Engraftment of hemopoietic cells. In: DW van Bekkum, B Lowenberg, eds. Bone Marrow Transplantation. New York: Marcel Dekker, 1985, pp 73-145.

112. RP Gale, Y Reisner. Graft rejection and graft-versus-host disease: Mirror images. Lancet 1:1468-1470, 1986.

113. H Plotnicky, JL Touraine. Promotion of fetal liver cell engraftment in irradiated mice by activated T lymphocytes. Bone Marrow Transplant 12:307-314, 1993.

114. RG Miller. An immunological suppressor cell inactivating cytotoxic $T$ lymphocyte precursor cells recognizing it. Nature 287:544-546, 1980.

115. BR Bloom, RL Modlin, P Salgame. Stigma variations: Observations on suppressor T cells and leprosy. Annu Rev Immunol 10:453-488, 1992.

116. WJ Burlingham, AP Grailer, JH Fechner, S Kusaka, M Trucco, M Kocova, FO Belzer, HW Sollinger. Microchimerism linked to cytotoxic $\mathrm{T}$ lymphocyte functional unresponsiveness (clonal anergy) in a tolerant renal transplant recipient. Transplantation 59:1147-1155, 1995.

117. RM Steinman, K Inaba, JM Austyn. Donor-derived chimerism in recipients of organ transplants. Hepatology 17:1153-1156, 1993.

118. K Inaba, RM Steinman, MW Pack, H Aya, M Inaba, T Sudo, S Wolpe, G Schuler. Identification of proliferating dendritic cell precursors in mouse blood. J Exp Med 175:1157-1167, 1992.

119. L Lu, WA Rudert, S Qian, D McCaslin, F Fu, AS Rao, M Trucco, JJ Fung, TE Starzl, AW Thomson. Growth of donor-derived dendritic cells from the bone marrow of murine liver allograft recipients in response to granulocyte/macrophage colonystimulating factor. J Exp Med 182:379-387, 1995.

120. AW Thomson, L Lu, Y Wan, S Qian, CP Larsen, TE Starzl. Identification of donorderived dendritic cell progenitors in bone marrow of spontaneously tolerant liver allograft recipients. Transplantation 60:1555-1559, 1995.

121. L Lu, J Woo, AS Rao, Y Li, SC Watkins, S Qian, TE Starzl, AJ Demetris, AW Thomson. Propagation of dendritic cell progenitors from normal mouse liver using granulocyte/macrophage colony-stimulating factor and their maturational development in the presence of type-1 collagen. J Exp Med 179:1823-1834, 1994.

122. L Lu, D McCaslin, TE Starzl, AW Thomson. Bone marrow-derived dentritic cell progenitors (NLDC $145^{\circ}, \mathrm{MHC}$ Class $\left.11^{+}, \mathrm{B} 7-1^{\mathrm{dim}}, \mathrm{B7-2^{- }}\right)$ induce alloantigen-specific hyporesponsiveness in murine $\mathrm{T}$ lymphocytes. Transplantation 60:1539-1545, 1995.

123. F Fu, Y Li, S Qian, L Lu, F Chambers, TE Starzl, JJ Fung, AW Thomson. Costimulatory molecule-deficient dendritic cell progenitors (MHC Class $11^{+}, \mathrm{B}^{-1^{\mathrm{vim}}, \mathrm{B7}^{-2}}{ }^{-}$) prolong cardiac allograft survival in non-immunosuppressed recipients. Transplantation 62:659-665, 1996.

124. H Waldmann, SP Cobbold, R Benjamin, S Qin. A theorectical framework for selftolerance as its relevance to therapy of autoimmune diseases. J Autoimmun 1:623-629. 1988.

125. TE Starzl. Experience in Hepatic Transplantation: Efforts 10 Mitigate or Prevent Rejection. Philadelphia: WB Saunders, 1969, pp 193-227.

126. GJV Nossal. Immunologic tolerance. In: F Rapaport. J Dausset, eds. Human Transplantation. New York: Grune \& Stratton, 1968, pp 643-654.

127. RH Levey. Immunological tolerance and enhancement: A common mechanism. Transplant Proc 3:41-48, 1971.

128. $\vee$ Murase. DG Kim. S Todo. DV Cramer. JJ Fung. TE Starzl. FK 506 suppression 
of heart and liver allograft rejection. 11. The induction of graft acceptance in rat. Transpiantation 50:739-744, 1990.

129. P Bretscher, M Cohn. A theory of self-nonself discrimination: Paralysis and induction involve the recognition of one and two determinants on an antigen, respectively. Science 169:1042-1049, 1970.

130. MR Jenkins, DM Pardoll, J Mizuguchi, TM Chused, RH Schwartz. Molecular events in the induction of a non responsive state of interleuken-2 producing helper $T$ lymphocyte clones. Proc Natl Acad Sci USA 84:5409-5414, 1987.

131. RH Schwartz. Immunological tolerance. In: WE Paul, ed. Fundamental Immunology, 3rd ed. New York: Raven Press, 1993, pp 677-731.

132. GJV Nossal, BL Pike. Functional clonal deletion in immunological tolerance to major histocompatibility complex antigens. Proc Natl Acad Sci USA 78:3844-3847, 1981.

133. B Arnold, G Schönrich, GJ Hämmerling. Multiple levels of peripheral tolerance. Immunol Today 14:12-14, 1993.

134. DL Vaux, A Strasser. The molecular biology of apoptosis. Proc Natl Acad Sci USA 93:2239-2244, 1996.

135. TC Pearson, DZ Alexander, R Hendrix, ET Elwood, PS Linsley, KJ Winn, CP Larsen. CTLA4-Ig plus bone marrow induced long-term allograft survival and donorspecific unresponsiveness in the murine model. Transplantation 61:991-1004, 1996.

136. JF Miller, G Morahan. Peripheral T cell tolerance. Annu Rev Immunol 10:51-69, 1992.

137. AM Posselt, CF Barker, JE Tomaszewski, JF Markmann, MA Choti, A Naji. Induction of donor-specific unresponsiveness by intrathymic islet transplantation. Science 249:1293-1295, 1990.

138. L Campos, AM Posselt, BC Deli, GL Mayo, K Pete, CF Barker, A Naji. The failure of intrathymic transplantation of nonimmunogenic islet allografts to promote induction of donor-specific unresponsiveness. Transplantation 57:950-953, 1994.

139. S Dejbakhsh-Jones, L Jerabek, IL Weissman, S Strober. Extrathymic maturation of $\alpha \beta$ T cells from hemopoietic stem cells. J Immunol 155:3338-3344, 1995.

140. TE Starzl, KA Porter, G Andres, CG Groth, CW Putnam, I Penn, CG Halgrimson, SJ Starkie, L Brettschneider. Thymectomy and renal homotransplantation. Clin Exp Immunol 6:803-814, 1970.

141. D Steinmuller. Immunization with skin isografts taken from tolerant mice. Science 158:127-129, 1967.

142. DNJ Hart, CG Winearls, JW Fabre. Graft adaptation: Studies on possible mechanisms in long-term surviving rat renal allografts. Transplantation 30:73-80, 1980.

143. NL Thai, TS Qian, F Fu, Y Li, H Sun, AJ Demetris, RJ Duquesnoy, TE Starzl, JJ Fung. Mouse liver transplantation tolerance: The role of hepatocytes and nonparenchymal cells. Transplant Proc 27:509-510, 1995.

144. Y Shimizu, S Goto, R Lord, G Vari, CE Smith, S Chiba, D Schlect, M Buckley, M Kusano, $N$ Kamada. Restoration of tolerance of rat hepatic allografts by spleenderived passenger leukocytes. Transplant Int 9:593-595, 1996.

145. JW Streilein. Neonatal tolerance of $\mathrm{H}-2$ alloantigens: Procuring graft acceptance the "old fashioned" way. Transplantation 52:1-10, 1991.

146. P Alard, JA Matriano, S Socarras, MA Ortega, JW Streilein. Detection of donorderived cells by polymerase chain reaction in neonatally tolerant mice: Microchimerism fails to predict tolerance. Transplantation 60:1125-1130, 1995.

147. RD Owen. Immunogenetic consequences of vascular anastomoses between bovine iwins. Science 102:400-401. 1945.

148. C Martinez. F Shapiro, RA Good. Essentual duration of parabiosis and development of toler ance to skin homogratis in mice. Proc Soc Exp Biol Med 104:256-259. 1960.

149. S Slavin, S Strober. Z Fuks. HS Kapian. Induction of a specific tissue transplantation tolerance using fractionated total lymphoid irradiation in adult mice: Long term suruval ot allogeneic bone marrow and skin gratts. J Exp Med 146:34-48. 1977. 
150. ST Ildstad, DH Sachs. Reconstitution with syngeneic plusallogeneic or xenogeneic bone marrow leads to specific acceptance of allografts or xenografts. Nature 307:168170, 1984.

151. J Thomas, M Carver, P Cunningham, K Park, J Gonder, F Thomas. Promotion of incompatible allograft acceptance in rhesus monkeys given posttransplant antithymocyte globulin and donor bone marrow. I. In vivo parameters and immunohistologic evidence suggesting microchimerism. Transplantation 43:332-338, 1987.

152. AW Thomson, AJ Demetris, N Murase, TE Starzl. Promotion of cell chimerism by immunosuppressive drugs: A possible basis for tolerance induction following organ transplantation. In: AW Thomson, TE Starzl, eds. Immunosuppressive Drugs: Developments in Anti-Rejection Therapy. London: Edward Arnold, 1994, pp 221-229.

153. TE Starzl, KA Porter, G Andres, CG Halgrimson, R Hurwitz, G Giles, PI Terasaki, I Penn, GT Schroter, J Lilly, SJ Starkie, CW Putnam. Long-term survival after renal transplantation in humans: With special reference to histocompatibility matching, thymectomy, homograft glomerulonephritis, heterologous ALG, and recipient malignancy. Ann Surg 172:437-472, 1970.

154. S Takemoto, PI Terasaki, DW Gjertson, JM Cicka. Equitable allocation of HLAcompatible kidneys for local pools and for minorities. N Engl J Med 331:760-764, 1994.

155. TE Starzl, AS Rao, M Trucco, P Fontes, JJ Fung, AJ Demetris. Explanation for loss of the HLA matching effect. Transplant Proc 27:57-60, 1995.

156. FT Rapaport, K Watanabe, FB Cannon, N Mollen, D Blumenstock, JW Ferrebee. Histocompatibility studies in a closely bred colony of dogs. IV. Tolerance to bone marrow, kidney, and skin allografts in DLA-identical radiation chimeras. J Exp Med 136:1080-1097, 1972.

157. FT Rapaport, RJ Bachvaroff, N Mollen, H Hirasawa, T Asano, JW Ferrebee. Induction of unresponsiveness to major transplantable organs in adult mammals. Ann Surg 190:461-473, 1979.

158. R Storb, RH Rudolph, HJ Kolb, TC Graham, E Mickelson, V Erikson, KG Lerner, H Kolb, ED Thomas. Marrow grafts between DLA matched canine littermates. Transplantation 15:92-100, 1973.

159. M Tanabe, N Murase, AJ Demetris, RA Hoffman, K Nakamura, S Fujisaki, FHF Galvao, S Todo, J Fung, TE Starzl. The influence of donor and recipient strains in isolated small bowel transplantation in rats. Transplant Proc 26:3733-3740, 1994.

160. PMH Mazumdar. Species and Specificity: An Interpretation of the History of Immunology. Cambridge: Cambridge University Press, 1995, p 457.

161. RB Gallagher, J Dilder, GJV Nossal, G Salvatore. Immunology: The making of a modern science. London: Academic Press, 1995, pp 1-246.

162. FS Rosen. The end of history. Nature 379:36, 1996.

163. P Fontes, A Rao, AJ Demetris, A Zeevi, M Trucco, P Carroll, W Rybka, C Ricordi, F Dodson, S Shapiro, A Tzakis, S Todo, K Abu-Elmagd, M Jordan, JJ Fung, TE Starzl. Augmentation with bone marrow of donor leukocyte migration for kidney, liver, heart, and pancreas islet transplantation. Lancet 344:151-155, 1994.

164. AS Rao, P Fontes, F Dodson, A Zeevi, MT Rugeies, $K$ Abu-Elmagd, A Aitouche, $G$ Rosner, M Trucco. AJ Demetris, W Rybka. S Todo, JJ Fung, TE Starzl. Augmentation of natural chimerism with donor bone marrow in orthotopic liver recipients. Transplant Proc 28:2959-2965, 1996.

165. R Garcia Morales, V Esquenazi, K Zucker. CI Gomez, L Fuller. M Carreno. R Cirocco, A Alamo. T Karatzas. GW Burke III. G Cianico. D Temple. H Fernandez. C Ricordi, A Tzakis. J Miller. Assessment of the effects of cadaver donor bone marrow on kidney allograit recipient blood cell chimerism by a novel technique combining PCR and tlow cytometry (PCR-FLOW). Transplantation 62:1149-1160, 1996. 